TURIZAM

Volume 22, Issue 4 158-167 (2018)

ORIGINAL

SCIENTIFIC PAPER

\title{
Strategic guidelines for the development of marinas in the segment of mega-yachts in The Republic of Croatia
}

\author{
Saša Škorić ${ }^{A}$, Srećko Favro ${ }^{B}$, Neven ŠerićC \\ Received: October 2018 | Accepted: December 2018 \\ DOI: 10.5937/turizam22-17398
}

\begin{abstract}
Nautical tourism is specific because it depends on maritime and coastal region, natural geographical prerequisites, specific infrastructure and many other specific environment factors. It consists of three segments, Charter tourism, Cruise trips and Marinas. Mega-yachts as subsegment of segment Marinas is very specific with high financial value in comparison with other elements of nautical tourism, but it is unattended in comparison to the other ones. The least represented subsegment of segment Marinas in the Republic of Croatia is Mega-yachts berths that should provide the greatest possibilities in terms of profit. There are not enough real data regarding future needs for mega-yachts berths in realized studies and made strategic guidelines. The aim of this research is making of strategic guidelines those can provide further growth and development of marinas in subsegment of mega-yachts, but it could also be a good backup for lot of other activities those are necessary for that segment of nautical tourism. It should assure their whole year residence in Croatia that would bring the economic development of marinas and it would speed up development of accompanying services, too. Five determined hypothesis have been tested and confirmed in this work. Two standard research methods were used. Secondary data were collected by research method round the table, while primary data were collected by query on Croatian and English language, with personal interviews and observations. The results from this research have shown that Croatia has the potential to attract the mega-yachts, offering various services and development of services for attracting the mega-yachts and extend the tourist season. All of the above-mentioned contributes to the hiring of the population, attracting the investments, increasing the economic standard and local community development.
\end{abstract}

Key words: Mega-yacht, strategy of marinas, factors of development, market of berths.

A3 d.o.o., 141 brigade 14, 21000 Split, Croatia, email: sasa.skoric@yahoo.com

B University of Split, Faculty of Economics, Split, Department of Tourism and Economics.

Corresponding author: srecko.favro@efst.hr

University of Split, Faculty of Economics, Split, Department of Marketing, email: neven.seric@efst.hr 


\section{Introduction}

Marinas are a crucial part of nautical tourism supply that deserve special attention because of the development of nautical offers which is in recent times an important segment of tourist supply in increasing number of countries. It has become an ever more important part of budget plans, in terms of costs and incomes. It is necessary, through a strategic approach, to maximize the potential use of marinas, they have started to gain an importance in last twenty years and their possibilities continue to progress.

One of the quite complete definition of the term nautical tourism is that it is a poly-functional tourist activity with a strong maritime component (Kizielewich, Luković, 2013).

Nautical tourism is specific by the fact that it primarily depends on coastal waters, natural prerequisites and specific infrastructure. It also depends on numerous other specific factors of the environment those are essential for its development such as legal regulation, human potential, media, state and district administration, supporting infrastructure, service industry, such as catering services and similar factors (Luković, 2013).

From an analitical point of view, nautical tourism is divided into three segments: Charter tourism, Cruise trips and Marinas. Within the segment of marinas, the segment of megayachts stands out from the other segments of nautical tourism overall by its specificity, financial value, marketing benefits, exclusivity, but also with its negligence (Luković, 2009).

Because of the above-mentioned reasons, one segment of nautical tourism in Croatia, marinas for mega-yachts, is the least represented, although it offers the greatest possibilities for improvements.

To define the steps and actions with the goal of an increase in the growth of representation of berths for mega-yachts, attracting their owners and ensuring their satisfaction with the services provided, it was necessary to determine the current state and conduct an analysis which would provide strategic goals for marinas for the berthing of mega-yachts in Croatia, following the trends of nautical tourism. The above-mentioned would increase the profits of marinas and accelerate the economic growth of the respective geographic area. It is of exceptional importance to identify all of the factors those contribute to ensuring the faster attraction of megayacht owners, as to further encourage the development of that segment.

The term mega-yacht has a somewhat different meaning than the one it had about twenty years ago, and today it usually specifies yachts longer than 24 meters, in certain cases even yachts longer than 40 meters. Most of nautical tourism leaders have made their own strategic guidelines of marina development. The leading countries on the Mediterranean are France, Greece, Italy, Spain, Croatia and recently Turkey (Gračan, Alkier Radnić, Vizjak, 2006).

There is almost no country with access to the sea that does not have a somewhat developed system for the vessels berthing and reception. On a global scale, the United States of America (USA) takes significant position with the biggest network of marinas, but also with significant investments into their further development (Laaksonen, 2012).

Some strategies are based on the development of marinas in the sense of supply increase of other tourist activities, such as strategy of the Port of Cannes in Cannes. Its task was to round up the supply of one already strong tourist city, which it has succeded; considering that, for example, during the Cannes Film Festival there was a need to reserve spots almost a year in advance (http://www.cnmarinas.com/marinas/index.htm).

An example of a different strategy is the development of Frapa marina in Rogoznica, which has literaly brought life to the town and inscribed it in the tourist map of Croatia. Marina Frapa has become a textbook example of how a marina can help in the development of the 
local comunity and contribute to the opening up new job positions and other accompanying branches, private accomodation development, etc. (Sušac, 2014).

This research should point out the lack of strategic managment in the segment of megayacht berthing in marinas. Also, the lack of understanding of the benefit that development of this segment ensures not only for marinas as business organisations which take care of the market of berthing mega-yachts, but also the external environment which needs to place itself into a supporting function for the development of this market.

\section{Materials and method}

The issues this work tackles is the construction of strategic guidelines with which marina managment can ensure the growth and development of marinas in the segment of mega-yachts berthing and in doing so give a wind to the sails of many other activities those requires that segment of nautical tourism.

The purpose of the research was to include all the relevant factors those could help in the process of obtaining extensive and detailed information on the research problem as well as the attitudes of people who have direct knowledge of the current state of the number of berths for mega-yachts in the marinas and the needs for them.

The examinees were encourged to think about certain elements that marinas offer in order to determine is it really possible to develop certain services those would ultimately be profitable and helpful in attracting mega-yachts users for berths, can it help marinas in promoting their services and efforts to fight for their share in the market of mega-yachts berths, which is growing at a faster rate than the other segments of the yacht market.

During research, special attention was directed towards the factors of satisfaction of the users of mega-yacht berths. Preliminary testing was conducted through the theoretical gathering of data, so it has provided the basis for formulating and conducting further phases of research. The gathering of primary data was designed to be conducted in two paralel steps: by interviews and questionnaires.

The oral interview has been conducted in the period from $15^{\text {th }}$ February 2017 to $31^{\text {st }}$ Decembar 2017 and has been included 48 people from the yacht segment: owners, crew, marina employees, but also others who may have certain insight into the advantages and eventual shortcomings of mega-yacht berthing. The goal was to design the guidelines for reviewing the key factors and composing a questionnaire. The questionnaires were in circulation for about 30 days, in the period from $1^{\text {st }}$ May 2017 to $15^{\text {th }}$ June 2017. They were used primarily to approach employees and mega-yacht owners and they were addressed to many big marinas, well-known mega-yachts owners, crew members and other service activities providers connected to the issues being researched. Therefore, it was received 55 responses from various target groups. The goal has also been to collect at least 15 responses from the mega-yacht owner group, and 17 were gathered, whose thoughts are crucial when it is discussed about what aditionaly could draw them to spend more time in the marinas in Croatia.

The gathered data were processed into two phases. In the first phase complete data were analyzed according to the questions, those had the purpose of concluding the certain traceability in the responses, so it was possible to define the attitudes of the examinees toward the subject of research. It has been investigated if a certain group of examinees prefered certain viewpoints according to their job position. 
By analyzing each individual issue, the aim was to reach a conclusion on the results of the research of a particular problem and eliminate the influence of the particular examined group. For example, most caterers with facilities near marinas consider that there is no need for new and luxoriy catering facilities because the existing supply is enough and it is capable to satisfy all needs those guests with mega-yachts might require. As opposed to them, captains and crewmen of mega-yacht think that the current offering of restaurants and catering facilities is not even approximately satisfying because problems occur during reservations and the organization of events and receptions for mega-yacht owners, especially with supply of certain gastronomic specialties, with quality and sparkling vines, but also with adequate space capacities in the sense of ensuring privacy. So personal preferences of certain groups have been minimized, that allows conclusions more precise.

The responses of the owners of mega-yachts have been analyzed in the second phase because they represent the market of berths for mega-yachts and they direct the further steps. In consideration of some possible responses those might be burden on personal preferences of respondents, hence the main analysis included equally all the examinees, while the analysis of the responses of mega-yacht owners was used for comparison with the conclusions of all the other examinees and as a guidepost how to achieve the desired condition and attract megayachts into the marinas.

By analyzing all the responses to a certain question a general viewpoint on the research matter was obtained, individual attitudes are united into a single whole, so it is the basis from which all the conclusions of this entire research were derived.

After the answers are summed it was done a calculation of the relative frequency of a share to a certain response in the total number of responses to a certain question followed, which means the share of a certain response in regards to the whole. The above-stated represents the power of an individual response respectively its frequency, from which it is possible to conclude how important a certain factor to resolving the presented problem is. Finally, the analysis of all the responses results in the final definition of the parameters for setting the goals and definition of strategic guidelines for the development of marinas in the segment of megayachts. After the conducted analysis for all the examinees, the respones from the group owners of mega-yachts were singled out.

Chi-square test was used after the conductied research and analysis of the obtained results to confirm the accuracy of hypotheses and the data processing was done by statistical program for data analysis Statistical Package for Social Sciences (SPSS).

\section{Results}

From conducted research, it can be concluded that state of offer of mega-yacht berths in the marinas of the Republic of Croatia does not satisfy the needs for them. There is an imbalance of supply and demand for mega-yacht berths in marinas.

The research has shown that $89.1 \%$ of examinees deems the legal regulations not adequatly defined. All the owners of mega-yachts consider the legal regulations act as non-stimulative and negative for the development of this branch of nautical tourism, deeming that this segment of the external environment of marinas needs to be upgraded. Among the most common complaints are unreliable, demotivating and poorly written legal regulations which are often subject to change and different interpretations while also they discriminate the local popu- 
lation in the sense of not being implemented equally for locals and foreigners, they are often confusing and nonlogical and there is incompatibility with regulations of the Europian Union.

In the past almost twenty years marinas in Croatia have made a huge progress in terms of the quality of service, number of berths, safety of navigation and protection of the environment. However, the segment of berths for mega-yachts and vessels longer than 40 meters and more has grown much more slowly when compared to the number of berths for smaller vessels. Even $87.3 \%$ of examinees deems that the supply of berths for mega-yachts in Croatia is not adequate to the demand. The owners of mega-yachts have similar thinking, $88 \%$ of them think that the berths for their vessels do not satisfy demand for them.

The leading reasons marinas do not develop in mega-yachts segment are shown by Figure 1.

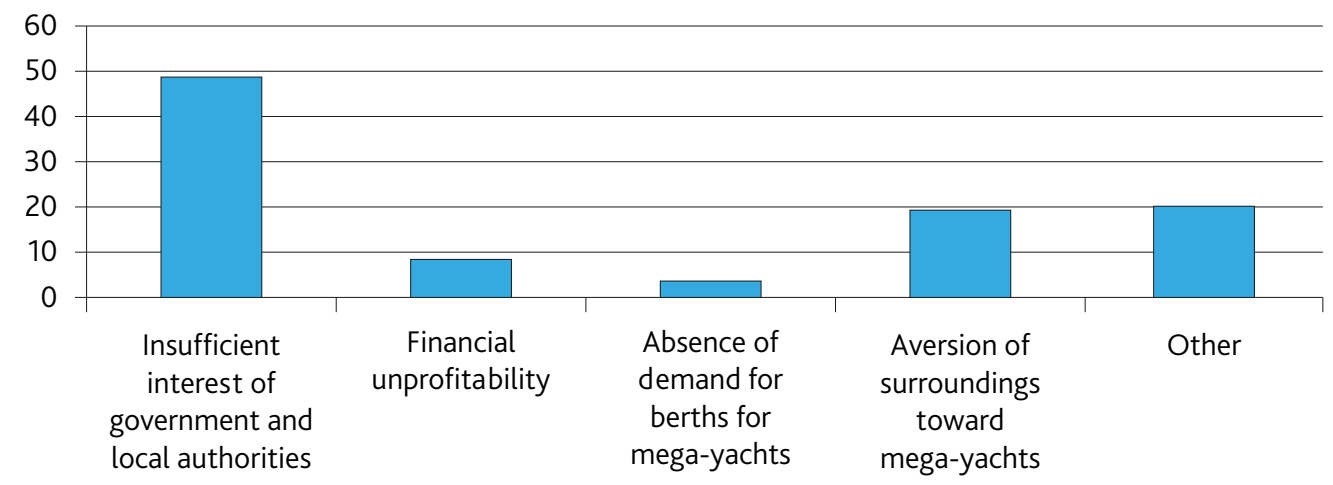

Figure 1. Main reasons marinas do not develop in mega-yacht segment (\%) Source: The author's research

As the main reason marinas do not develop in mega-yachts segment is concluded to be insufficient interest of state and local authorities with $48.3 \%$.

The factors which the examinees deem crucial for the development of marinas in the segment of mega-yachts are the safe berth for mega-yachts with all the necessary supporting infrastructure with $44.6 \%$, then airlines and transportation connections with $24.3 \%$, catering, sports and similar services with $14.9 \%$, and finally an insured elite space for the berth and interests in the wider geographical area with $5.4 \%$ each. In total, $47.8 \%$ of mega-yacht owners consider that most important factor is safe berth for mega-yachts with all the required supporting infrastructure, $26.1 \%$ of them consider it is an insured elite space for the berth and the same number of them also think the reason is the aerial and transportion connections of marinas.

Figure 2. shows the attitudes of the examinees related to the importance of reasons for non-developing marinas, at least at the rate the market requires.

The main factors in attracting the mega-yachts are the construction of additional infrastructure (28.8\%) and the adjusting of legal regulations (23.3\%). Among the owners of megayachts, $40.9 \%$ of them consider that the construction of infrastructure is to be the most important factor, then adjustment of legal regulations with $22.7 \%$ and $18.2 \%$ other examines think that the most important factor is the isolation of berths, ensuring the sports, catering and similar activities.

It is observed the activities which are developed by attracting new users of mega-berths, which is shown by Figure 3 . 


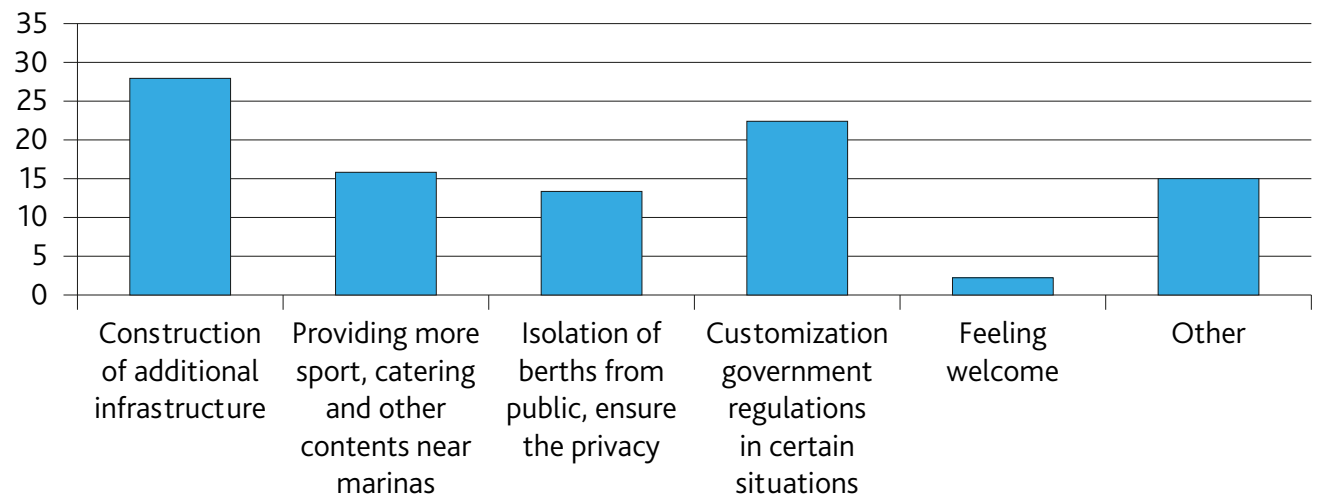

Figure 2. The attitudes on the subject of what attracts mega-yachts owners (\%) Source: The author's research

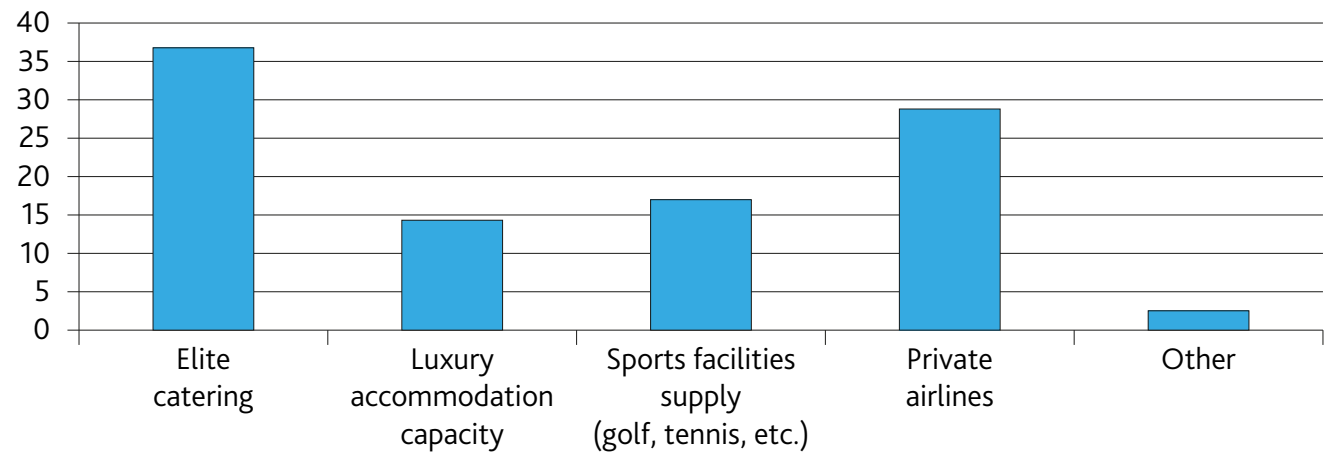

Figure 3. The attitudes of examinees regarding the additional activities development in related to the attracting mega-yachts (\%)

Source: The author's research

The most important activity is private airlines services considered by the owners of megayachts in $39.1 \%$ of cases, elite catering in $30.4 \%$ and the offer of sport activities in $21.7 \%$ of cases. The rest of the respondents consider the luxurious residence capacities as the best activity in the function of attracting users of mega-berths. The owners of mega-yachts contribute to the development of certain specific services just by visit considering they are a clientele with an exceptionally high paying ability.

What specific services has been developed by the growth of the number of stays of megayacht owners can be shown by Figure 4. When the only viewpoints of mega-yacht owners are observed, it is noticed that $42.9 \%$ of them consider that specific types of transportations are primarily being developed such as private airlines services and taxi services. A total of $28.6 \%$ examinees consider that the supply of exclusive designer and other brands is being developed, 14.3\% chose the various recreational and catering services and $9.5 \%$ considers the beauty treatment services, cosmetic and spa centers where the staying of mega-yacht owners will contribute to the development.

The greatest number of examinees considers legal regulation the greatest barrier in the development of the mega-yacht market, the structure of which can be observed by Figure 5 . In total $32.0 \%$ of mega-yacht owners consider legal regulations the main obstacle in marina development, with $20 \%$ presented that the main problem is the insufficient number of support- 
ing services and berths, while $12 \%$ owners deem the poor supply of maintenance services and other ones necessary for that type of vessel.

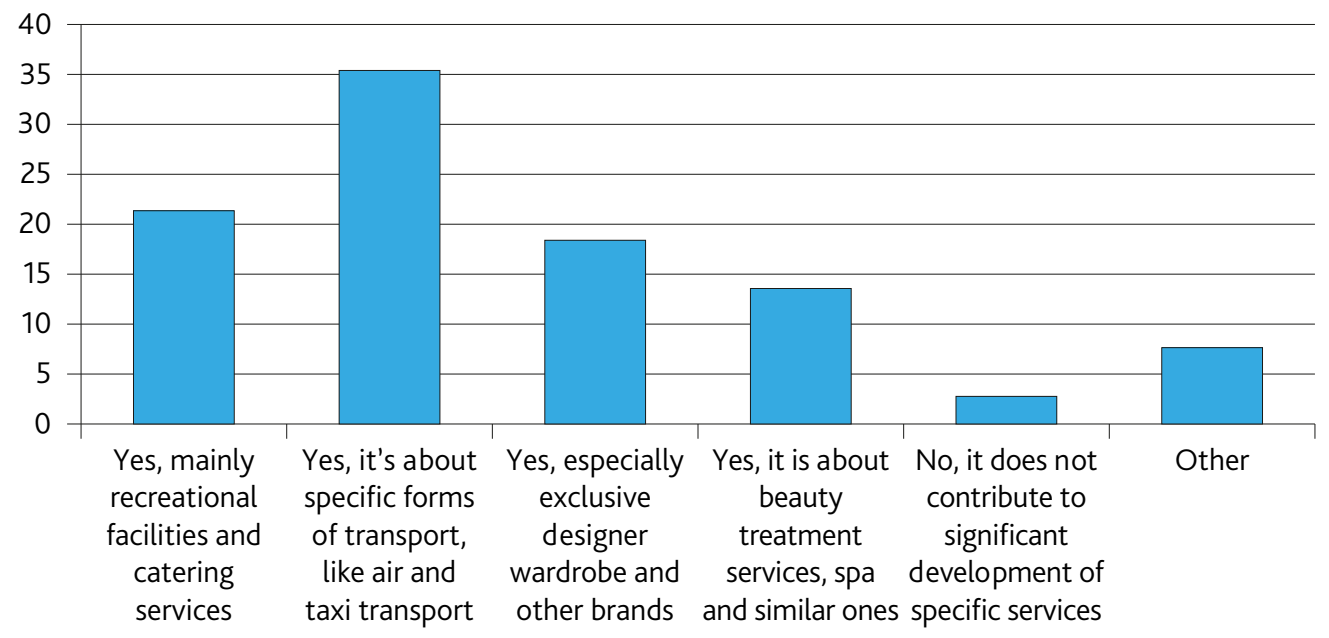

Figure 4. The attitudes of the examinees on the development of various specific services (\%) Source: The author's research

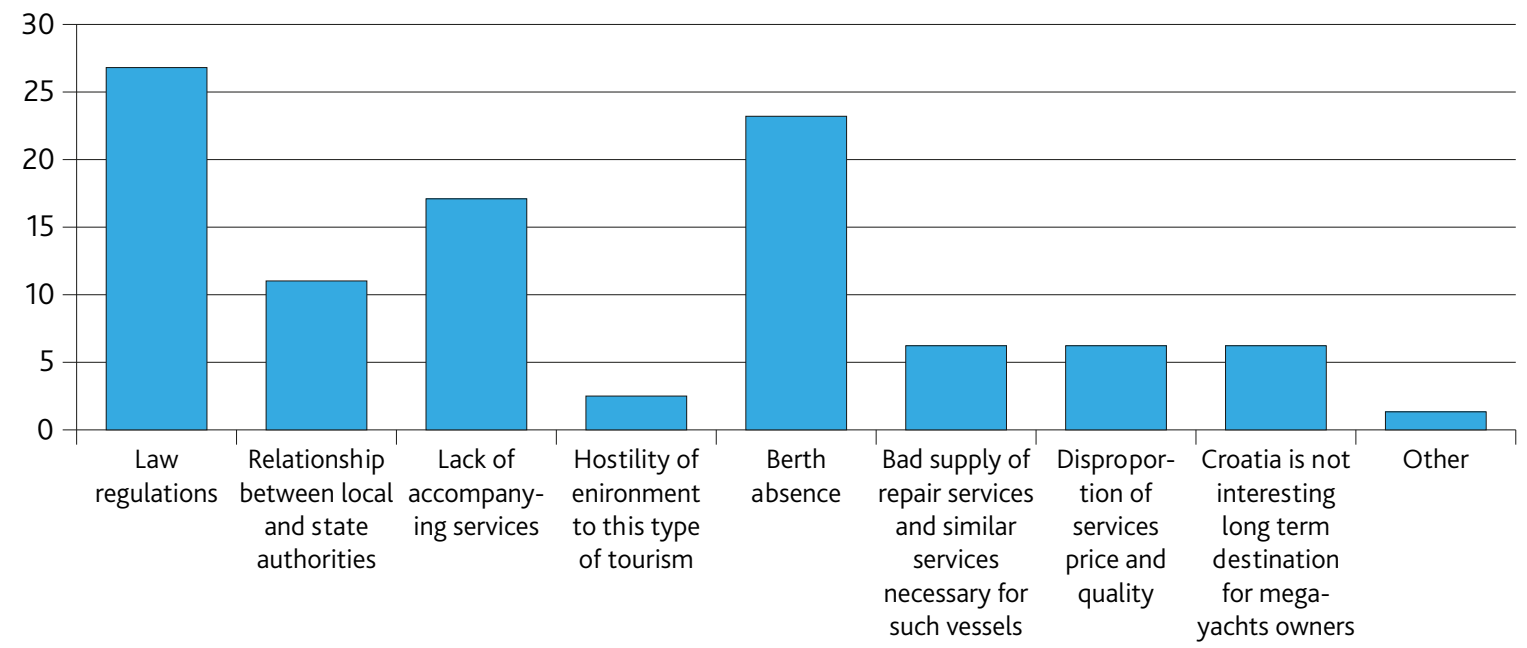

Figure 5. Attitudes of respondents regarding the obstacles in development of berth market of mega-yachts in Croatia (\%) Source: The author's research

The rest of the surveyed mega-yacht owners equally consider that the main developoment barrier is the relationship between local and state administrations, the aversion of the environment towards this type of tourism, the disproportion of services price and quality and finally Croatia is not so interesting long-term destination for mega-yachts owners.

The Republic of Croatia has several documents those, somewhat, present the current state and give insight into the desired state, which is mean to be achieved. Surely, one of the most important one is the Strategy for the development of Nautical Tourism of the Republic of Croatia for the period of 2009 to 2019 that was ordered both, by Ministry of the Sea, Transport 
and Infrastructure and Ministry of Tourism. (Ministry of Tourism, 2008). Within the Strategy, it is not mentioned more detailed elaboration nor a definition of specific goals and certain deadlines.

In total $70.6 \%$ of mega-yacht owners are not familiar with the strategy, while $5.9 \%$ of owners are familiar with the strategy but they think it needs additional development. The same number of examinees think that the strategy is adequate presented, so the additional development and presentation are not required. The rest of them state that a strategy for the development of marinas in the segment of mega-yachts does not exist in any form.

The greatest number of mega-yacht owners thinks that ensuring a favorable climate for the development of new services in the environment in the function of attracting new megayacht owners, it is of key importance for $32.1 \%$ of them in fact, while $28.6 \%$ of owners think that adjusting of legal regulations is most important. $17.9 \%$ of examinees consider ensuring additional services strategicaly relevant to marinas to be most important, while $14.3 \%$ consider that it is key to define the growth of number of berths.

The fact is that the Strategy for the Development of the Nautical Tourism of the Republic of Croatia contains only a part of the factors that the respondents stated as essential, without the detailed elaborationt of the marina development for the mega-yacht segment. It is an important segment of nautical tourism and the potential within a branch that has quite a fast growth to take advantage of it and catch up with other states those have recognized the opportunities provided by mega-yachts acceptance.

\section{Conclusion}

The basic task of this work is making of guidelines for the aligning of strategic goals of marinas for the acceptance of mega-yachts in Croatia with the trends in nautical tourism. The above stated should be resulted not only in the economic growth of marinas and their usefulness, but also the development of series of various supporting services. It would encourage hiring of the local population that would in turn ensure the economic growth and development of the geographic area in which the marina is located.

Many negative factors of the development of marinas in the segment of mega-yachts have been recorded. Some of them are identified as key: basic infrastructure and legal regulations. The solution to these issues is a prerequisite for ensuring that the basic requirements for attracting mega-yachts are met. Numerous other factors are also important and should be implemented into the offerings, especially those serivces and activities which ensure the longer stays of mega-yachts and satisfy specific needs, such as maintenance services and various specialized services in the branches of IT, telecommunication and woodworking. Elite catering, luxurious residence capacities, private airlines and taxi services, sport activities and luxury clothes stores are just some of the services those would benefit and get their markets develop further by attracting mega-yachts. Independently of their importance, all factors and elements should be taken into consideration when defining the strategy and the strategic guidelines. This allows to achieve the full effect of strategic planning and assures the realization of the maximum potential of that segment of nautical tourism. That way would ensure the entire suport to activities toward achieving their strategic goals.

Research has shown the viewpoints of mega-yacht owners concerning certain issues, which has resulted by the gathering of information on the thinking of the people who represent the market of berths demand for mega-yachts. It is important to understand that it is about a cli- 
entele that demands specific treatment in the form of simple regulations and procedures, the ability to resolve certain issues within a short time, privacy, and luxury. They have the means and the resources to choose a place anywhere all over the world for their stay. It is necessary to position themselves at the top of the tourist supply by supply and quality in the segment of mega-yachts.

The following hypothesis have been set and confirmed. More berths capacity for megayachts contributes to the economic growth and performances of marinas. It is sets up the connection between the growing number of berths for mega-yachts and the growing economic performances of marinas. The hypothesis that defines the interdependence of the existing mega-yacht berths and the attracting of mega-yacht owners suggests that an existing infrastructure is a prerequisite for attracting mega-yacht owners. Namely, without an adequate infrastructure that ensures a safe berth, there is no base condition for the berthing of megayachts in marinas. Adequate reallocation of existing marina resources is needed. That means that marinas with a speific infrastructure those can be subjected to an adequate conversion towards the function of berthing mega-yachts, they have all the prerequisites required to develop complementary marina services in the function of serving mega-yachts. That is about specific services which require a certain level of knowledge and specific technologies which are not represented often with smaller vessels. It is also about quality of processing materials and materials themselves that are characteristic for highly luxurious vessels. The interdependence of adjustment of legal regulations in connection with the users of mega-yachts berths and loyality of users toward Croatia as nautical destination related to certain legal simplificarions of procedures, interpretations and the alignment of legal regulations in Croatia but also the alignement of legal regulations in Croatia with international legal ones. So, it is confirmed the need of adjustments of certain legal regulations due to attracting the mega-yacht owners. By the last hypothesis it was confirmed the assumption that attracting mega-yachts encourages the development of series of supporting marina activities. It is related to the products and services supply such as luxurious restaurants, private airlines services, various luxuriy clothes stores, unique products sale and products characterized by advanced technology and high price.

The confirmed hypotheses have additionaly indicated the need for strategic planning in the form of managing marinas in the segment of mega-yachts and the implementation of the results of conducted research.

For the strategy to has been adequatly implemented, it has to be presented to the public in a clear and understandable way by explaining its goals, stating the expected period of their achievment and defining the benefits which are expected from the results of implementations. Often, the public has a negative viewpoint towards mega-yachts due to the pollution of the environment and unresponsible behavior concerning nautical and security regulations, but that simply is not correct.

Finally, the strategy should be defined so that the goals clearly sets and defines its goals so their achievements and progress can be continualy monitored and the process of the implementation could be controled and in the end its goals can be realised. Croatia has the potential for all above mentioned; it is important to react adequatly and in time so the opportunities provided could be taken advantage. 


\section{References}

Kizielewich, J. Luković, T. (2013). The Phenomenon of the Marina Development to Support the European Model of Economic, TransNav, The International Journal of Marine Navigation and Safety of the Sea Transportation, p.p. 461-466.

Luković, T. (Ed.) 2013. Nautical Tourism. University of Dubrovnik Croatia.

Luković, T. 2009. Pomorstvo, god. 23, br. 2, Sukobljene ili sukladne strategije razvoja europskoga nautičkog turizma, 341-356. (in Croatian)

Gračan, D. Alkier Radnić, R. Vizjak, A. 2006. Razvoj nautičkog turizma na Mediteranu, Pomorski zbornik 44, Društvo za proučavanje i unaprjeđenje pomorstva Republike Hrvatske, Rijeka, p.p. 123-137. (in Croatian)

Laaksonen, T. 2012. A Market Analysis on the Global Boating Industry, Tampere University of Applied Sciences

Sušac, A. 2014. Diplomski rad: Planiranje i projektiranje luka nautičkog turizma sa naglaskom na marine za prihvat mega jahti, Sveučilište u Rijeci, Pomorski fakultet Rijeka, Rijeka. (in Croatian)

Strategija razvoja nautičkog turizma Republike Hrvatske, 2008. Ministarstvo mora, prometa i infrastrukture, Ministarstvo turizma, Zagreb (in Croatian)

Favro, S., Kovačić, M. (2010). Nautički turizam i luke nautičkog turizma, Ogranak Matice hrvatske Split (in Croatian)

Internet 1: http://www.cnmarinas.com/marinas/index.htm (16.02.2018)

Internet 2: http://www.marinafrapa.com/ (13.02.2018) 